\title{
REVISITANDO O INSTITUTO DO TRESPASSE REVISITING
}

\author{
THE INSTITUTE THE GOODWILL AGREEMENT
}

\begin{abstract}
${ }^{1}$ Maria Luiza Firmiano Teixeira
\section{RESUMO}

O presente estudo tem como objetivo revisar criticamente o contrato de trespasse, conhecido como "passa-se o ponto", com o objetivo de levantar as disposições codificadas sobre o tema, apresentando leitura atual e sistêmica. Trata-se de contrato atípico, complexo e de grande relevância econômica, inclusive para a promoção da livre iniciativa, que começa a necessitar de revisão doutrinária a partir da revolução tecnológica e inserção da internet no mundo dos empreendimentos.
\end{abstract}

Palavras-chave: Trespasse, Contrato, Efeitos obrigacionais

\begin{abstract}
This study aims to critically review the goodwill agreement in order to raise the provisions encoded on the subject, presenting current and systemic reading. It is atypical contract, complex and of great economic importance, including the promotion of free enterprise, which begins in need of doctrinal revision from the technological revolution and insert the internet in the world of enterprises.
\end{abstract}

Keywords: Sale of business premises, Contrac, Dividend effects

\footnotetext{
${ }^{1}$ Mestranda em Direito Universidade do Estado do Rio de Janeiro - UERJ, Rio de Janeiro, RJ. Auditora Interna do Instituto Federal do Sudeste de Minas Gerais - IF SUDESTE MG, Minas Gerais, MG. (Brasil). E-mail: marialuizaft@gmail.com.
} 


\section{INTRODUÇÃO}

O instituto objeto deste estudo não é nenhuma novidade doutrinária ou legal, na verdade é um instituto amplamente conhecido, com previsão em vários ordenamentos pelo mundo. Trata-se do trespasse, contrato voltado para a alienação do estabelecimento empresarial.

Inspirado no Direito Italiano, o Código Civil de 2002, trouxe disposições essenciais quanto aos efeitos deste negócio jurídico em seus artigos 1.144 a 1.149, eu servem de base para este estudo. Não se pretende esgotar o tema ou realizar um trabalho meramente descritivo, mas sim um trabalho que contribua com algumas visões cítricas.

Para tanto o artigo foi dividido em três partes, quais sejam: uma introdução geral sobre o contrato, contendo conceito, diferenciações e formalização; uma segunda parte relativa aos efeitos do contrato previstos no Código Civil, em que se analisou criticamente as disposições legais sobre o tema, buscando conjugar com a nova principiologia privada, bem como conjugando os interesses comerciais e os interesses de terceiros e; uma quarta parte, que é uma introdução a discussão do trespasse no caso do estabelecimento virtual.

A metodologia empregada neste trabalho foi a pesquisa documental, nos mais amplos meios, isto é, bibliotecas físicas, digitais, revistas on-line, entre outros.

Espera-se com este trabalho dar uma pequena contribuição ao tema, apresentando questões mais detalhadas e polêmicas presentes na doutrina, fugindo da análise rasteira que normalmente se vê, ademais pretende apontar para a possibilidade legal da existência de um trespasse virtual, isto é, dispensada sede física ou meramente formal.

\section{O QUE É TRESPASSE?}

O trespasse é nome dado à transmissão do estabelecimento empresarial, tomado aqui como conjunto de bens organizados para o exercício da empresa. Trata-se de contrato bilateral que retira o complexo de bens corpóreos e incorpóreos ${ }^{1}$, envolvidos com a exploração de uma atividade empresarial, da titularidade do alienante. Nas palavras de FÉRES (2007, p. 46):

Importante observar que Rubens Requião (05; p. 180) entende que os bens imóveis não compõem o estabelecimento empresarial: "Estudamos que os imóveis ( $n^{\circ} 163$ infra) não integram o fundo de comércio, o que ocorre também com o passivo". 
O trespasse é, pois contrato bilateral, comutativo, em que as partes se obrigam à realização de prestações economicamente equivalentes, sob pena de enriquecimento sem causa de uma delas.

Consiste ele em mecanismo de aquisição derivada da titularidade do estabelecimento, o que sujeita o seu adquirente a experimentar as vicissitudes da universalidade formatada no passado.

Em consonância com o conceito colacionado acima será possível observar que, em certos casos, a aquisição implica em receber, igualmente, obrigações referentes ao conjunto de bens.

Não se trata de contrato típico, portanto, segue a natureza do conjunto de bens transferidos. Via de regra, aplica-se, no que couber, o disposto no contrato de compra e venda, embora a operação possa ser realizada com a constituição de vários contratos diferentes para atender as formalidades legais para cada variedade de bem transferido.

IV Jornada de Direito Civil. Enunciado 393 - Art. 1.143: A validade da alienação do estabelecimento empresarial não depende de forma específica, observado o regime jurídico dos bens que a exijam

Importante observar que o contrato de trespasse não se confunde com o contrato de transferência de bens singulares, location-gérance (contrato de exploração do estabelecimento), cessão simultânea da totalidade das quotas ou ações de uma sociedade, ou cisão (transmissão de unidades economicamente funcionais).

A venda de coisa singular, ainda que pertencente ao estabelecimento comercial, é possível, desde que possa ser efetuada a sua venda sem a perda de seu caráter econômico diante da separação dos demais elementos. Evidentemente, no caso de venda singular, aplicarse-á o disposto na legislação relativa aquela forma de bem. Ao trespasse, no entanto, aplicamse as regras específicas previstas no Código Civil entre os artigos 1.142 a 1.149.

Também não pode ser confundido com a location-gérance, prevista no Código Civil francês, no Capítulo IV, art. 144-1 ${ }^{2}$. Segundo TURCHETTI (2014), o instituto ganhou importância no sistema francês após a Segunda Guerra Mundial, quando um grande número de pessoas adquiriu estabelecimentos ou com a finalidade de explorar pessoalmente ou para alugar a outrem.

\footnotetext{
2 "Nonobstant toute clause contraire, tout contrat ou convention par lequel le propriétaire ou l'exploitant d'un fonds de commerce ou d'un établissement artisanal en concède totalement ou partiellement la location à un gérant qui l'exploite à ses risques et périls est régi par les dispositions du présent chapitre".
} 
A location-gérance diz respeito a um arrendamento do estabelecimento empresarial, em que se permite separar a titularidade da azienda do poder de uso e gozo. Em palavras sintéticas:

(...) permite o desmembramento entre a titularidade primária e a titularidade secundária, cabendo ao arrendatário o direito à exploração da azienda e consequente aferição de lucro pelo exercício da atividade empresarial, assumindo este, contudo, os riscos da atividade, bem como todos os direitos e obrigações inerentes.

Ao arrendador cabe o valor mensal a ser pago pelo arrendatário, e, ao término do contrato, o estabelecimento restituído nas mesmas condições em que foi entregue para arrendamento. (TURCHETTI; 2014, p.71)

Fácil observar então que o trespasse não guarda relações com essa forma de arrendamento do Direito Francês, pois no caso em comento o estabelecimento será efetivamente alienado, e a titularidade integral será entregue ao adquirente.

Também não se pode confundir o trepasse com a cessão simultânea da totalidade das quotas ou ações de uma sociedade. No segundo caso, sem dúvidas, não ocorre a mudança da titularidade do estabelecimento, pois este estava e continua sob a titularidade da sociedade empresária. De fato, a transferência das quotas societárias implica na alienação da participação societária e não na alienação do conjunto de bens corpóreos e incorpóreos que compõem o estabelecimento comercial. Entretanto, é preciso observar que, dependendo do montante da participação no capital social transferido, pode gerar uma alteração no poder de controle ou na maioria do capital social, surgindo a possibilidade de mudança do objeto social e, consequentemente, a destinação da sociedade. Desta alteração pode surgir o trespasse.

Por fim, o trespasse é diferente da cisão. Forma de reorganização societária, a cisão é o processo pela qual uma sociedade empresária transfere parcelas do seu patrimônio para uma ou mais sociedades, constituídas para este fim ou já existentes. Há a cisão total quando ocorre a versão de todo seu patrimônio e parcial quando não for integral a transferência. No primeiro caso, aplicam-se as regras da incorporação, as sociedades que recebem o patrimônio da cindida serão solidariamente responsáveis pelas suas obrigações. No segundo caso, a sociedade cindida transfere parte de seu patrimônio para outras, mas não se exaure nesta atividade, continuando sua atuação econômica. Neste sentido, a cisão parcial e o trespasse se aproximam. Para diferenciar os institutos, é preciso entender que na cisão o patrimônio é transferido com a contraprestação de subscrição de novas ações que serão emitidas de acordo com o patrimônio adquirido. Estas ações serão integralizadas de imediato e oferecidas aos 
acionistas da cindida (art. 229, §5, Lei 6.404/76). Assim, não é o caso de uma simples cessão de ativo. (CARVALHOSA, 1997; p.292).

Em outras palavras, no trespasse o alienante não tem qualquer interesse em compor quadro societário, sua intenção é obter retorno, em forma de pecúnia, com a venda daquele conjunto organizado de bens. Não se aplicam ao trespasse qualquer das disposições da Seção II da Lei das Sociedades Anônimas.

Também não se confunde o trespasse com o disposto no artigo 647 do Código de Processo Civil. Segundo a legislação processual é possível satisfazer o credor mediante usufruto de bem móvel ou imóvel. Este dispositivo foi modificado em 2006, pela lei 11.382, que retirou do texto a expressão "ou de empresa", ou seja, o legislador admitia que o usufruto recaísse sobre a sociedade empresária. $\mathrm{O}$ assunto volta à tona com o projeto do novo código de processo civil (lei 13.105) que no artigo 825 admite "apropriação de frutos e rendimentos de empresa ou de estabelecimentos e de outros bens" como forma de expropriação. Não se trata de trespasse, pois não se verifica alienação da universalidade de fato que o estabelecimento empresarial representa. Ocorre aqui apenas a separação dos benefícios econômicos que o estabelecimento pode gerar para o credor ressarcir-se, ou seja, não há modificação de titular do estabelecimento e sim redirecionamento de seus frutos para o usufrutuário credor.

Finalizando a parte conceitual primária, é importante frisar que vige para o contrato de trespasse os deveres anexos trazidos pela aplicação da boa-fé objetiva. Em especial, por se tratar de contrato atípico, portanto, pouco disciplinado pela legislação vigente, é importante destacar o dever de informar e o due diligence. Nas palavras de MACHADO e SALEME (2014; p.3):

O conceito da Devida Diligência origina-se na legislação americana 'Securities Act' dos EUA de 1933, que se refere à Comissão de Valores Mobiliários. A norma prevê diligência prévia em defesa de compradores e vendedores na prestação de informações relevantes, evitando possíveis fraudes em procedimentos de aquisição de empresas (USA, 2014).

Também objetiva assegurar o dever de cuidado, protegendo o vendedor contra possível responsabilização, desde que se demonstre que a informação em falta não havia sido descoberta, não obstante as diligências realizadas de boa fé nesse sentido.

Neste sentido cabe ao alienante e ao adquirente averiguar a verdadeira situação do estabelecimento empresarial quando da realização do contrato de venda. Prevalecendo o dever 
de informar antes, durante e após o contrato, tendo em vista a aplicação da boa-fé contratual em todas as fases da relação ${ }^{3}$.

Para finalizar as questões iniciais e proceder a análise das disposições positivadas no Código Civil, cumpre perquirir o momento de ocorrência do trespasse. Parece uma pergunta tola, mas não o é se se pensar na possibilidade do trespasse parcial.

É possível que o estabelecimento não seja repassado em sua totalidade, isso é possível porque como bem lembra WALD (2005; p.728) citando Requião, cada bem guarda a sua individualidade, porém, agregados possuem um valor maior ${ }^{4}$.

Admitindo-se, portanto, o trespasse parcial, em que momento considera-se ocorrido o evento de alienação se não existir instrumento formalizador específico? Segundo FÉRES (2007; p.51) a regra é a da funcionalidade, isto é, considera-se realizado o trespasse se o conjunto de bens transmitidos for capaz de operar como estabelecimento. Assim sendo, é possível concluir que cada caso deverá ser verificado, no sentido de observar os elementos essenciais para que se dê o trespasse parcial.

Neste sentido foi emitido o enunciado 233 da III Jornada de Direito Civil: "Art. 1.142: A sistemática do contrato de trespasse delineada pelo Código Civil nos arts. 1.142 e ss., especialmente seus efeitos obrigacionais, aplica-se somente quando o conjunto de bens transferidos importar a transmissão da funcionalidade do estabelecimento empresarial".

Vencida a parte inicial de caracterização do instituto, passa-se agora a analisar os dispositivos do Código Civil referentes ao tema.

\section{EFEITOS OBRIGACIONAIS DECORRENTES DA ALIENAÇÃO DO ESTABELECIMENTO}

O estabelecimento empresarial não possui personalidade jurídica, logo não titulariza direitos e deveres, entretanto, várias relações são constituídas para o exercício de empresa e influenciam o estabelecimento, daí as disposições do Código Civil.

Os três principais efeitos dizem respeito à transferência dos contratos, transmissão de dívidas e de créditos.

\footnotetext{
${ }^{3}$ Embora o artigo 422 do Código Civil não disponha expressamente sobre a aplicação da boa-fé objetiva na fase pré-contratual não merece acolhida uma interpretação restritiva, pois afastaria da relação contratual a determinação de lealdade desde as primeiras tratativas, não coadunando com o espírito da lei.

${ }^{4}$ A possibilidade de trespasse parcial está longe de ser pacífica, alguns autores parecem não admitir esta situação, como exemplo, vejamos o disposto no trabalho de Daniela Palhares Turchetti, citado aqui anteriormente, bem como o Código Civil Interpretado Conforme a Constituição da República, comentários ao art. 1.142, da editora Renovar.
} 


\title{
3.1 TRANSFERÊNCIA DOS CONTRATOS
}

A transferência dos contratos está prevista no artigo 1.148 do Código Civil, que assim dispõe:

\begin{abstract}
Art. 1.148. Salvo disposição em contrário, a transferência importa a subrogação do adquirente nos contratos para exploração do estabelecimento, se não tiverem caráter pessoal, podendo os terceiros rescindir o contrato em noventa dias a contar da publicação da transferência, se ocorrer justa causa, ressalvada, neste caso, a responsabilidade do alienante.
\end{abstract}

O dispositivo trata da sub-rogação automática do adquirente nos contratos existentes, este efeito não existe em outras legislações, isto é, não é um efeito obrigatório. Entretanto, para que isso ocorra é necessário que sejam preenchidos os seguintes requisitos: (I) que se trate de contrato bilateral; (II) de caráter exploracional; (III) que sejam contratos impessoais; (IV) inexista cláusula em sentido contrário; (V) inexista óbice legal; (VI) que não haja justa causa para o terceiro rescindir o contrato.

Contrato bilateral é aquele em que existem direitos e obrigações para todas as partes envolvidas. O caráter exploracional significa que somente os contratos referentes ao negócio sofrerão a sub-rogação; também não podem ter caráter personalíssimo, isto é, executável somente pelo sujeito inicialmente contratado, daí a exigência da impessoalidade. Por fim, exige-se a inexistência de qualquer disposição no sentido contrário, seja advinda da lei, seja do próprio contrato e não pode haver justa causa para que o sub-rogado rescinda o contrato, ou seja, uma situação de fato que justifique o incumprimento da obrigação. Nas palavras do Professor Fábio ULHOA (2012; p 121): “caracterizam-na fatos como a não aprovação do novo fiador apresentado, existência de protestos em nome do adquirente, ou de ações judiciais intentadas contra este, sua situação patrimonial, econômica ou financeira insatisfatória ao atendimento das condições normalmente exigidas pelo locador etc".

Existe ainda sobre o tema certa celeuma quanto ao contrato de locação. Embora o enunciado número 08 da I Jornada de Direito Comercial trate o contrato de locação como incluso na sub-rogação, a doutrina entende que se trata de contrato regido por legislação especial, dependendo de requisitos próprios. Desta forma, para que haja a sub-rogação no contrato de locação é essencial o consentimento prévio e escrito do proprietário do imóvel para que possa ocorrer a cessão (art. 13 da lei 8.245/91). Nesse sentido opinam Arnoldo Wald, Modesto Carvalhosa e os comentários no Código Civil Interpretado Conforme a Constituição 
da República. Eis que na III Jornada de Direito Civil o entendimento se modificou: "Enunciado 234 - Art. 1.148: Quando do trespasse do estabelecimento empresarial, o contrato de locação do respectivo ponto não se transmite automaticamente ao adquirente. Fica cancelado o Enunciado n. 64".

No intuito de espantar qualquer dúvida, a jurisprudência analisou o tema, e considerou o contrato de locação com caráter intuito personae, portanto, impossível a transferência sem o consentimento, conforme acórdão do Recurso Especial n 1.202.077/MS do STJ:

\section{LOCAÇÃO COMERCIAL. TRESPASSE.}

Trata-se de ação de despejo por falta de pagamento cumulada com ação de cobrança dos aluguéis; o primitivo locador realizou a cessão do fundo de comércio a terceiros (trespasse), o que, a seu ver, exonerá-lo-ia da responsabilidade por ulteriores débitos locatícios em razão da inaplicabilidade do art. 13 da Lei n. 8.245/1991 aos contratos de locação comercial. Apesar da relevância do trespasse para o fomento e facilitação dos processos produtivos e como instrumento para a realização do jus abutendi (o poder de dispor do estabelecimento comercial), ele está adstrito a certos limites. $\mathbf{O}$ contrato locatício, por natureza, reveste-se de pessoalidade, pois são sopesadas as características individuais do futuro inquilino ou fiador (capacidade financeira e idoneidade moral), razão pela qual a alteracão deles não pode dar-se sem o consentimento do proprietário do imóvel. Assim, não há como entender que o referido artigo da Lei do Inquilinato não possa ser aplicado às locações comerciais, visto que, ao prevalecer o entendimento contrário, tal qual pretendido pelo recorrido, o proprietário do imóvel estaria à mercê do inquilino, que, por sua conveniência, imporia ao locador honrar o contrato com pessoa diversa daquela constante do instrumento, que pode não ser apta a cumprir o avençado por não possuir as qualidades exigidas pelo proprietário.

(grifos meus)

Ainda é preciso um alerta, para que essas transferências tenham valor diante de terceiros envolvidos nesses contratos, o trespasse deve ser averbado diante da junta comercial, publicado na imprensa oficial e em jornal de grande circulação, conforme artigo 1.144 do Código Civil.

Apesar da disposição legal, existe uma observação referente ao enunciado 489 da $5^{\text {a }}$ Jornada de Direito Civil. Segundo este, as microempresas, as empresas de pequeno porte e o microempreendedor individual, ficam dispensados de publicação dos seus atos (art. 71 da Lei Complementar $n^{\circ}$ 123/2006), inclusive no caso do trespasse. Nessa situação, o prazo estabelecido no art. 1.148 conta-se da data do arquivamento do documento (termo inicial) no registro próprio. 
Por fim, o dispositivo em comento fala da responsabilidade do alienante no caso de rescisão pelo adquirente, mas nada estabelece sobre a abrangência da reparação. No entanto, não é possível admitir outro entendimento que não a reparação do adquirente e do terceiro envolvido, já que não é dado a ninguém causar prejuízo a outrem.

Quanto ao primeiro, "não sendo obtida a aquiescência do terceiro, cabe ao adquirente voltar-se contra o alienante para haver indenização por lhe ter transferido menos do que ajustara". Quanto ao segundo, fica o alienante obrigado a indenizar, "tendo em vista que a justa causa para rescisão surgiu em virtude do negócio jurídico e das circunstâncias que o envolveram". WALD (2005; p.760)

Finalizada a análise do artigo 1.148, passa-se agora ao artigo 1.146 e a transferência das dívidas.

\subsection{TRANSFERÊNCIA DAS DÍVIDAS}

Conforme disposto no artigo 1.146 do Código Civil são de responsabilidade do adquirente os débitos anteriores à alienação, desde que deles tivesse ciência via contabilização, no entanto, permanece co-obrigado o alienante, solidariamente, "pelo prazo de um ano, a partir, quanto aos créditos vencidos, da publicação, e, quanto aos outros, da data do vencimento".

Esquematicamente, o dispositivo pode ser assim expresso:

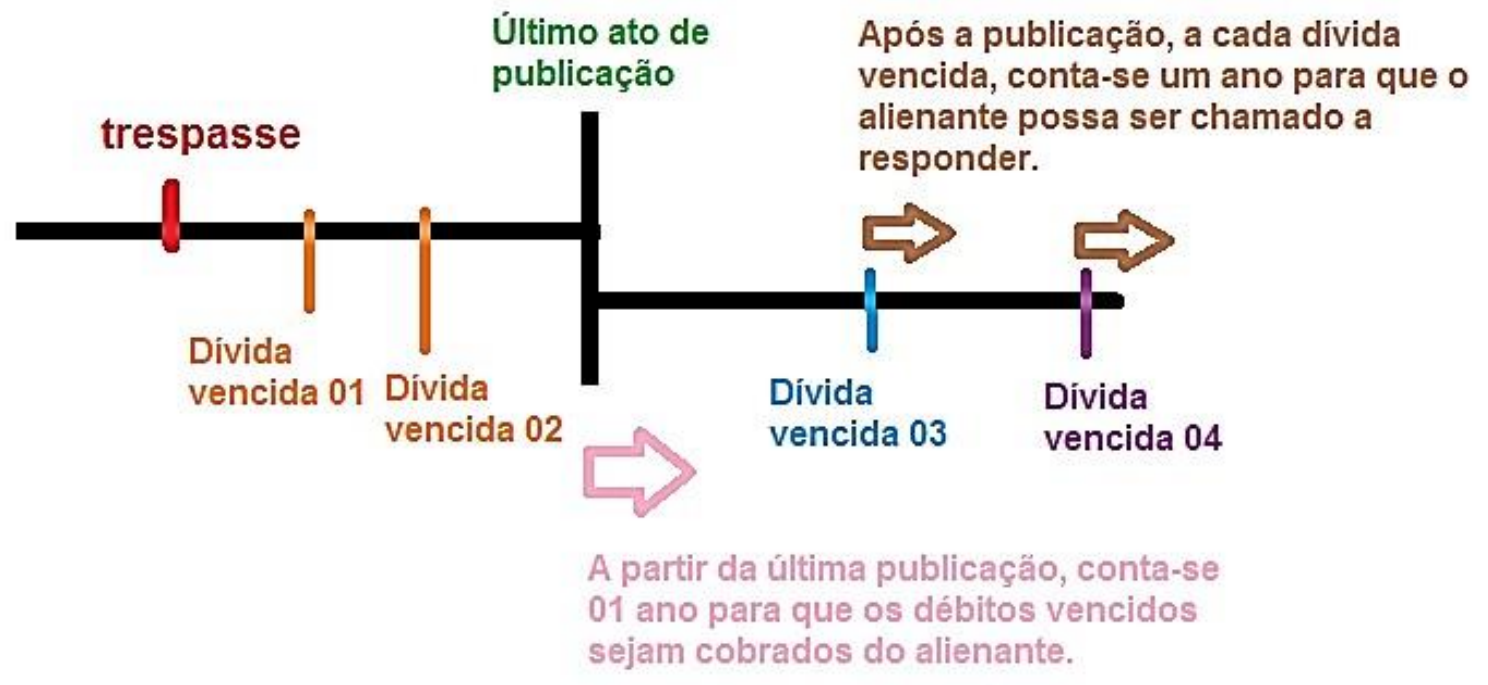

Figura 1- Esquema representando o disposto no artigo 1.146 do Código Civil Fonte: Elaborado pela autora 
Do esquema acima é possível observar que quanto às dívidas vencidas 01 e 02 (adquiridas antes mesmo do trespasse), conta-se o prazo para a cobrança solidária do último ato de publicação. Já para as dívidas vencidas após a publicação do último ato do trespasse, no caso as dívidas 03 e 04 , o prazo decadencial de um ano corre tendo em vista as datas de vencimento de cada uma delas.

Insta ressaltar que a contabilização não deve se dar por vias paralelas, é preciso que se revista da forma empresarial ou ainda ser preparada em documento apartado. Não importa também que seja separada por estabelecimento ou unificada, mas é essencial que esteja formalmente distinta.

Veja-se, então, que ocorre uma transferência paulatina da responsabilidade pelo adimplemento, mas que acaba por reforçar o pagamento, já que teremos dois credores disponíveis. É preciso observar ainda que no caso de dívidas trabalhistas e tributárias não existe a limitação relativa à escrituração. Cada ramo possui suas próprias regras. A Consolidação das Leis do Trabalho, em seu art. 10 e 448 dispõem que a mudança na propriedade ou estrutura da sociedade empresária não afeta os contratos de trabalho. Trata-se de verdadeira sucessão legal.

Quanto à questão tributária, aplica-se o disposto no artigo 133 do Código Tributário Nacional. O adquirente é o responsável tributário pela obrigação principal, independentemente da qualidade do estabelecimento ou de qualquer acordo entre as partes.

\footnotetext{
Art. 133. A pessoa natural ou jurídica de direito privado que adquirir de outra, por qualquer título, fundo de comércio ou estabelecimento comercial, industrial ou profissional, e continuar a respectiva exploração, sob a mesma ou outra razão social ou sob firma ou nome individual, responde pelos tributos, relativos ao fundo ou estabelecimento adquirido, devidos até à data do ato:

I - integralmente, se o alienante cessar a exploração do comércio, indústria ou atividade;

II - subsidiariamente com o alienante, se este prosseguir na exploração ou iniciar dentro de seis meses a contar da data da alienação, nova atividade no mesmo ou em outro ramo de comércio, indústria ou profissão.
}

Importante questão refere-se ao caráter obrigatório ou não do disposto no art. 1.146 do Código Civil. De fato as questões trabalhistas e tributárias estão positivadas e possuem caráter de norma de ordem pública, inafastáveis. Mas e quanto às demais obrigações, seria possível estabelecer regra diversa no contrato, colocando o alienante, definitivamente, fora da relação? 
Em um primeiro momento a resposta nos parece negativa, até pelo caráter de proteção que a norma significa para o terceiro de boa-fé. Neste sentido ilumina Arnoldo WALD (2005; p.742):

O artigo 1.146 do novo Código Civil regula a sucessão das obrigações relativas ao estabelecimento e a responsabilidade do adquirente e do alienante em relação a terceiros. Note-se, o contrato de trespasse é instrumento hábil para regrar amplamente a responsabilidade de cada parte, bem como o modo de sucessão entre elas. Uma vez que as partes podem pactuar entre si os efeitos que desejam produzir no trespasse, o objetivo primeiro desta norma consiste em proteger terceiros, cujas pretensões não podem ser prejudicadas em face do negócio realizado. Portanto, a regra de responsabilidade prevista nesse artigo tem caráter obrigatório, aplicando-se em favor de terceiros independentemente do disposto no contrato de alienação.

No entanto, o que parece inadmissível é deixar o terceiro desguarnecido, estabelecendo algum tipo de "vácuo" de responsabilização. Interpretando sistematicamente o ordenamento percebe-se que existe forma de isentar o alienante de responsabilidade, trata-se da assunção de dívida. Veja-se o texto legal do Código Civil: “Art. 299. É facultado a terceiro assumir a obrigação do devedor, com o consentimento expresso do credor, ficando exonerado o devedor primitivo, salvo se aquele, ao tempo da assunção, era insolvente e o credor o ignorava". Portanto, havendo aceitação por parte dos credores em um contrato de assunção de dívida, o alienante pode deixar a relação solidária, cabendo somente ao adquirente o compromisso de quitar os valores devidos. Nesse sentido opina FÉRES (2007; p. 123), indicando que o art. 1.146 é uma norma vinculatória aos sujeitos do trespasse, portanto, terceiros credores poderiam anuir em uma assunção de dívida.

Outra relevante questão refere-se ao abatimento no preço dos valores das dívidas escrituradas. Se o alienante, ao celar o acordo com o adquirente, confere-lhe um desconto no valor inicial em virtude dos débitos existente e, mais tarde, vem a ser cobrado por eles, via ação de terceiro, caberia algum regresso contra o adquirente? Para FÉRES (2007; p.124) é um caso de enriquecimento sem causa, representando verdadeiro desequilíbrio contratual.

É certo que, na hipótese, haveria um desequilíbrio patrimonial dos sujeitos envolvidos na avença. Apesar da inexistência de disposições expressas, o alienante não ficaria desamparado. O Direito rechaça situações de ruptura do equilíbrio econômico. 
Por conseguinte, caberá o alienante a ação de enriquecimento sem causa, recobrando, nos limites do que dispendiou, dos valores que pagou em face de terceiros, em face do adquirente.

Para a finalização deste tópico é preciso analisar uma última situação, aquela referida no art. 1.145: "Se ao alienante não restarem bens suficientes para solver o seu passivo, a eficácia da alienação do estabelecimento depende do pagamento de todos os credores, ou do consentimento destes, de modo expresso ou tácito, em trinta dias a partir de sua notificação".

Mais uma vez o Código impõe regra de proteção ao interesse de terceiros, criando uma condição de eficácia para o trespasse. Em caso de impossibilidade de o credor saldar todas as suas dívidas quando da venda do estabelecimento deverá notificar seus credores em busca de consentimento. Por vezes, a identificação da solvência ou não é complexa, daí ser prudente praticar a notificação sempre que a situação fática dê margem a um entendimento diverso quanto à capacidade de honrar dívidas por parte do alienante.

Importa discutir aqui se qualquer dos credores poderia se insurgir contra o trespasse. FÉRES (2007; p.129) defende que não é lícito que qualquer credor se insurja contra o ato, isso porque boa parte deles estará resguardado pela existência do adquirente. Por força do art. 1.146 viu-se que as dívidas contabilizadas são, igualmente, de responsabilidade do adquirente, portanto, para o autor, não seria legítimo impedir a continuidade do negócio se não existe risco de não pagamento, já que o adquirente responderá pelo valor devido.

Com efeito, pelo negócio de alienação do estabelecimento, o adquirente se torna solidariamente responsável pelas dívidas regularmente contabilizadas, de conformidade com o disposto no art. 1.146. Ademais, os titulares de dívidas fiscais e trabalhistas, segundo os respectivos regimes jurídicos, também têm a possibilidade de cobrar do novo titular da azienda, aproveitando, para tanto, a invocação do art. 1.145 apenas aos credores que não encontram no adquirente responsabilidade por seus créditos. (FÉRES; 2007, p.129)

Este entendimento pode sofrer críticas pela interpretação extensiva da lei. Em outros termos, quando a lei quis excepcionar o direito, dirigindo-o a apenas alguns credores, ela o fez, portanto, o entendimento alhures implica em criar uma regra que a lei não trouxe. Ademais, desfaz o reforço da garantia e coloca o terceiro de boa-fé em situação de risco.

Professor ULHOA (2012; p.123) ressalta que essa questão é geralmente resolvida com a disposição contratual de assunção integral das dívidas pelo adquirente: 
Para evitar a ineficácia do trespasse, bem como para administrar diretamente os passivos de algum modo ligados ao estabelecimento que passa a assumir, o adquirente costuma contratar com o alienante a assunção de todas as obrigações. É comum - e atende, em geral, à conveniência dos empresários contratantes - a inserção de cláusula, no trespasse, que transfere ao adquirente a responsabilidade pela solução das dívidas pendentes do alienante, ligadas ao estabelecimento transacionado. Normalmente, em anexo ao instrumento contratual, relacionam--se os débitos e identificam-se os credores e valores correspondentes, para maior segurança quanto à extensão da obrigação assumida pelo comprador do estabelecimento.

Vale mencionar, que na Lei de Falências (11.101/05) existe a expressa determinação da não transferência dos ônus ao adquirente quando da venda do estabelecimento para fins de ressarcir os credores com aquele valor.

Art. 141. Na alienação conjunta ou separada de ativos, inclusive da empresa ou de suas filiais, promovida sob qualquer das modalidades de que trata este artigo:

(...)

II - o objeto da alienação estará livre de qualquer ônus e não haverá sucessão do arrematante nas obrigações do devedor, inclusive as de natureza tributária, as derivadas da legislação do trabalho e as decorrentes de acidentes de trabalho.

Essa previsão pretende, nas palavras de BARBOSA (2012; p. 105) a "maximização do valor dos ativos do falido, sua otimização na distribuição entre credores (respeito às garantias contratuais), culminando com o incentivo ao investimento, o empreendedorismo responsável e a redução do custo de crédito".

Passa-se agora a transferência de crédito, prevista no art. 1.149.

\subsection{TRANSFERÊNCIA DE CRÉDITOS}

Mais abrangente que o art. 1.148, a cessão de créditos parece engloba todos os créditos referentes ao estabelecimento: "Artigo 1.149 - A cessão dos créditos referentes ao estabelecimento transferido produzirá efeito em relação aos respectivos devedores, desde o momento da publicação da transferência, mas o devedor ficará exonerado se de boa-fé pagar ao cedente".

A posição majoritária da doutrina entende que todos os créditos referentes ao negócio se transmitem, no entanto, em dissonância encontra-se Marcelo FÉRES (2007; p.140), que defende que somente os créditos escriturados devem ser transmitidos. 
A transmissão se dá de forma automática e opera-se do último ato de publicação, não demandando notificação dos devedores, uma vez que a própria publicação do ato de trespasse possui esse caráter de informar e tornar de amplo conhecimento a alienação. Essa "facilidade" na transmissão se justifica por dois fundamentos: transmitem-se as obrigações após um ano da publicação do trespasse ou da data de vencimento das dívidas, portanto, para os créditos existem débitos correspondentes; além disso, a cessão de créditos reforça a garantia dos credores quando a responsabilidade passa a se somente do adquirente.

Existe uma exceção, no entanto, referente ao disposto no art. 286 do Código Civil: "O credor pode ceder o seu crédito, se a isso não se opuser a natureza da obrigação, a lei, ou a convenção com o devedor; a cláusula proibitiva da cessão não poderá ser oposta ao cessionário de boa-fé, se não constar do instrumento da obrigação". Essa cláusula que impossibilita a cessão deverá estar inserida no instrumento da obrigação cedida.

A lei resguarda o devedor de boa-fé que paga o alienante. Cabe ao adquirente demonstrar que o cedido estava de má-fé no ato de pagamento. Portanto, o desconhecimento por parte do devedor é suficiente para afastar responsabilidade futuras, daí continuar valendo a recomendação de que se notifique, mesmo que não seja obrigatório, os devedores do estabelecimento.

Quanto à responsabilidade do alienante pelos créditos cedidos o Código nada dispõe, assim, invoca-se as regras gerais da lei civil para amparar o caso. Aplicam-se os art. 295 ao 297. Em suma: o alienante responde pela existência do crédito (sob pena de enriquecimento sem causa) e, salvo disposição em contrário, não responde pela solvência do devedor.

Exceção a regra da não responsabilidade pela solvência é a transferência do estabelecimento a título de realização de capital social. Neste caso responderá pela solvência nos termos do art. 10 da lei 6.404/76 e o art. 1.005 do Código Civil:

Art. 10. A responsabilidade civil dos subscritores ou acionistas que contribuírem com bens para a formação do capital social será idêntica à do vendedor.

Parágrafo único. Quando a entrada consistir em crédito, o subscritor ou acionista responderá pela solvência do devedor.

Art. 1.005. O sócio que, a título de quota social, transmitir domínio, posse ou uso, responde pela evicção; e pela solvência do devedor, aquele que transferir crédito.

É possível que as regras gerais sejam afastadas por disposições contratuais neste caso, ressalta-se, contudo que a responsabilidade, por parte do alienante, pela solvência do devedor 
está adstrita aos limites daquilo que receberia do devedor, com os respectivos juros e despesas que o adquirente tenha tido com a cobrança (FÉRES; 2007 p.144).

Para finalizar a análise das consequências do trespasse, resta o disposto no art. 1.147, a chamada cláusula de interdição da concorrência.

\subsection{CLÁUSULA DE INTERDIÇÃO DA CONCORRÊNCIA}

Prevista no art. 1.147, determina que na ausência de cláusula expressa, o alienante não pode fazer concorrência ao adquirente durante cinco anos. Ou seja, não pode se reestabelecer, no mesmo negócio, de forma a ofertar concorrência com o alienante. O fundamento desta cláusula é a proteção da clientela, elemento essencial a manutenção do negócio.

Embora sem previsão no Código Civil de 1916, ainda assim era muito utilizada, e invocável via aplicação da boa-fé e da proteção das justas expectativas.

Com efeito, o adquirente de um estabelecimento empresarial tem como escopo a aquisição dos bens economicamente organizados, mas, muitas vezes, também visa o acesso à clientela do alienante. Embora não seja elemento integrante do estabelecimento, a clientela, para o adquirente pode representar parte essencial do negócio jurídico, principalmente nos casos de aquisição de estabelecimento de venda direta ao consumidor. Seria contrário ao princípio obrigacional da boa-fé que o alienante, sem anuência do adquirente, simplesmente retornasse a prática da mesma atividade negocial em território próximo, de forma a concorrer diretamente com o comprador. (WALD; 2005, p.749)

Entretanto, podem as partes pactuar de modo diverso no contrato, seja liberando totalmente a concorrência ou estabelecendo normas diversas para que ela ocorra. As regras estabelecidas em contrato devem pautar-se pela boa-fé e delimitar quatro elementos: espacial, temporal, pessoal e material. No quesito temporal no estabelecimento da cláusula privada restava dúvida se seria preciso ou não seguir o critério dos cinco anos estabelecidos na legislação civil. A certeza que se tinha era que deveria haver limitação e em sendo maior o prazo, estaria sujeita ao controle judicial da proporcionalidade:

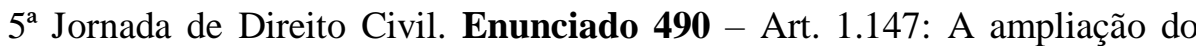
prazo de 5 (cinco) anos de proibição de concorrência pelo alienante ao adquirente do estabelecimento, ainda que convencionada no exercício da autonomia da vontade, pode ser revista judicialmente, se abusiva 
Entretanto, no ano de 2015, o STJ, no Recurso Especial no 680.815 /PR, trouxe decisão que limitou o lapso temporal em cinco anos:

RECURSO ESPECIAL. PROCESSUAL CIVIL, CIVIL E EMPRESARIAL. ACÓRDÃO ESTADUAL DEVIDAMENTE FUNDAMENTADO. INEXISTÊNCIA DE MALFERIMENTO AOS ARTS. 165, 458, II E III, E 535, II, DO CPC. "CLÁUSULA DE NÃO RESTABELECIMENTO". AUSÊNCIA DE VIOLAÇÃO AOS ARTS. 166, II E VII, E 421 DO CÓDIGO CIVIL DE 2002. PRAZO INDETERMINADO DA REFERIDA CLÁUSULA. ABUSO. LIMITAÇÃO TEMPORAL. NECESSIDADE. PRAZO DE 5 ANOS. CRITÉRIO DO ART. 1.147 DO CC/2002. NÃO CARACTERIZAÇÃO DE INFRAÇÃO À ORDEM ECONÔMICA. DISSÍDIO JURISPRUDENCIAL NÃO DEMOSTRADO. RECURSO PARCIALMENTE PROVIDO.

(...)

2. É válida a cláusula de "não restabelecimento" no tocante ao seu objeto, rejeitando-se a alegada violação ao art. 166, II e VII, do Código Civil de 2002, pois é regra comum nos negócios jurídicos que envolvem transmissão de direitos sobre estabelecimentos, amplamente utilizada no cotidiano empresarial. Insta mencionar que o CC/2002 inovou ao trazer expressamente, no seu art. 1.147, a "cláusula de não restabelecimento".

3. O art. 421 de CC/2002 positivou o princípio da função social dos contratos como limitador da liberdade de contratar, inexistindo violação a essa norma, no estabelecimento da cláusula de "não restabelecimento", usual na realidade empresarial para coibir a concorrência desleal.

4. Mostra-se abusiva a vigência por prazo indeterminado da cláusula de "não restabelecimento". pois o ordenamento jurídico pátrio. salvo expressas excecões, não se coaduna com a ausência de limitacões temporais em cláusulas restritivas ou de vedacão do exercício de direitos. Assim. deve-se afastar a limitação por tempo indeterminado. fixando-se o limite temporal de vigência por cinco anos contados da data do contrato, critério razoável adotado no art. 1.147 do CC/2002. (...) (grifos meus) 
Como se observar, o Superior Tribunal de Justiça considerou válida a imposição da interdição, porém abusiva se não delimitada temporalmente, sendo razoável a adoção do máximo de cinco anos.

Embora a questão ainda não tenha sido examinada pelos tribunais, é importante que a cláusula fixe também o espaço, isto é, a interdição vigora para a cidade X ou para o bairro Y? A definição do espaço coaduna $\mathrm{cm}$ a livre concorrência, permitindo que o alienante retome o negócio sem ferir o direito do adquirente. Já a definição pessoal atende a boa-fé objetiva e evita a instituição de fraudes, em outros termos, se a cláusula nada dispuser aplica-se a interdição a outras pessoas que não ao próprio alienante, mesmo que elas sejam muito próximas a ele? Para evitar transtornos de verdadeiros "desvios" da norma, é relevante a definição da extensão pessoal da cláusula, se aplicável somente ao alienante ou não. Por fim, a definição material implica que não redija cláusula no sentido de impedir totalmente o exercício da atividade econômica do alienante, estabelecendo, por exemplo, que não poderá empreender em qualquer área ou em área muito diversa do empreendimento alienado. Esse tipo de cláusula cerceia a livre iniciativa e, por consequência, viola a Constituição Federal.

Em suma, trata-se de cláusula justa e necessária, mas que deve ser redigida tendo em vista a livre iniciativa e o dever de boa-fé objetiva.

Para finalizar este trabalho reservou-se um tema relativo a própria modificação da forma de empreender. Com o surgimento do e-commerce, com a existência de estabelecimentos puramente virtuais, como se daria o trespasse? Passa-se ao interessante tema, com a intenção de introduzir o tema para futuras reflexões.

\section{O TRESPASSE E O ESTABELECIMENTO VIRTUAL}

$\mathrm{O}$ advento da informática, seu crescimento em conjunto com a rede mundial de computadores e as facilidades que eles trouxeram para o mundo moderno são inegáveis. De fato, parece um processo irreversível. Além da facilidade de comunicação enormemente aumentada, a internet também trouxe enormes influências para o comércio e o empreendedorismo. O crescimento do consumo, bem como dos empreendedores virtuais é enorme. Segundo dados veiculados na mídia em 2015 (EXAME):

A E-bit, empresa especializada em informações do setor, projetou nesta segunda-feira que o faturamento do e-commerce no país registrará um salto nominal de 20 por cento neste ano, atingindo 43 bilhões de reais. Em 2014, o crescimento foi de 24 por cento, e em 2013, de 28 por cento. 
(...)

No ano passado, o setor movimentou 35,8 bilhões de reais, somando 103,4 milhões de encomendas, com um tíquete médio de compra de 347 reais, segundo a empresa.

Desta forma, o Direito não pode se furtar de analisar as novas situações que surgem. Relacionado ao tema em análise temos algumas importantes indagações, a primeira delas seria sobre a existência ou não do estabelecimento empresarial virtual. A pergunta parece simples, mas não é. Pela doutrina majoritária, os sítios eletrônicos são apenas elementos incorpóreos do estabelecimento físico.

Na verdade, a existência da sede é uma obrigatoriedade para a própria personificação da sociedade, assim sendo, formalmente, sem a existência do estabelecimento físico não existe o virtual. Todavia, de fato, existem sociedades que desenvolvem todo o seu objeto virtualmente, existindo uma sede apenas para fins formais ou ainda para a guarda de servidores de rede. Neste caso, parece legítimo defender que o espaço virtual onde se exerce o objeto empresarial seria uma forma de estabelecimento empresarial.

Tiene razón João Eunápio Borges, al admitir que todo y cualquier emprendedor de actividad económica organizada para la producción de bienes, comercialización de bienes o la prestación de servicios, siempre tienen un establecimiento, aunque no fijado en parte física alguna (inmóvil), pues ineludiblemente hará uso de capital y trabajo. Aunque la iniciativa sea estructurada sin la presencia de una tienda física, necesitará de un ordenador, de uno o más programas de ordenador, de un servidor de internet, etc. Pero es preciso admitir que estos bienes pertenezcan al establecimiento físico principal, la matriz, que se considera distinto de aquella organización de la web, un verdadero establecimiento virtual. (NEVES; 2014, p.397)

Admitindo assim que existe um estabelecimento virtual, ainda que seja filial, é possível aplicar a ele as regras do trespasse.

Importante observar também que para sociedades não personificadas, por exemplo, uma sociedade em comum, a exigência de sede está superada, portanto, possível o estabelecimento virtual.

Para esses casos existe o trespasse em sua modalidade total ou parcial, com as regras já analisadas neste dispositivo, guardando cuidados quanto o caráter diferenciado dos bens que compõem um estabelecimento virtual, como o domínio, eventualmente a marcar, entre outros, que possuem regramento específico. Além disso, demanda análise mais específica a realidade da concorrência, tendo em vista a enorme abrangência do e-commerce. Neste 
aspecto, a regra estabelecida no artigo 1.147 não será suficiente para resolver o caso, o que demandará maior reflexão sobre a concorrência virtual, matéria nova até mesmo para o Direito da Concorrência.

Interessante notar que o Poder Legislativo também observou a mudança de fato do comércio. Este ano o Senado aprovou o Projeto de Lei da Câmara (PLC), que permite aos empreendedores individuais exercerem a atividade em sua própria residência, sem a necessidade de dispor de estabelecimento para essa finalidade ( AGÊNCIA SENADO; 2016), portanto, o trespasse, caso exista, certamente não se referirá ao ambiente em que se declara como sede dos trabalhos e sim aos demais componentes daquele negócio.

\section{CONCLUSÃO}

O presente estudo teve como objetivo rever o instituto do trespasse previsto no Código Civil de forma crítica e sistêmica.

Do estudo empreendido foi possível observar que se trata de instituto de grande relevância econômica e bastante controvertido doutrinariamente.

Para melhor compreendê-lo faz-se necessária atenção à técnica na identificação do estabelecimento empresarial, bem como seus elementos.

Observou-se ainda que toda a disposição sobre o tema está envolta de grande preocupação com o terceiro de boa fé e principalmente que não é possível, na atual conjuntura, interpretar qualquer cláusula que seja sem atenção à boa fé objetiva e o dever de diligência.

Não se trata de contrato simples, ao contrário, além e atípico é de intensa complexidade, gerando inúmeras consequências obrigacionais aos contratantes, até mesmo pela variedade de bens que envolve, guardando relação até mesmo com as ideias de concorrência desleal e livre iniciativa.

Por fim, levantou-se um ponto ainda pouco estudado pela doutrina, qual seja, o estabelecimento virtual. Mesmo sem maiores detalhamentos doutrinários, de pronto é possível perceber que nem todo o regramento previsto para o trespasse será passível de aplicação para o estabelecimento virtual tendo em vista suas peculiaridades, cabendo, assim, maior estudo sobre o tema, o que não foi foco deste trabalho. 


\section{BIBLIOGRAFIA}

BRASIL. Agência Senado. Senado aprova permissão para microempreendedor exercer atividade em casa. Disponível em:< http://www12.senado.leg.br/noticias/materias/2016/03/29/senado-aprova-permissao-paramicroempreendedor-exercer-atividade-em-casa>. Acesso em: 10 de abril de 2016.

BRASIL. Conselho da Justiça Federal. Jornadas de Direito Civil. Disponível em:< http://www.clarissabottega.com/Arquivos/Familia/Enunciados\%20CJF.pdf>. Acesso em: junho de 2015.

Lei 6.404 de 15 de dezembro de 1976. Dispõe sobre as sociedades por ações. Diário Oficial [da] República Federativa do Brasil, Brasília, DF, 17 dez. 1976. Disponível em: < http://www.planalto.gov.br/ccivil_03/leis/L6404compilada.htm>. Acesso em: setembro de 2015.

Lei 10.406 de 10 de janeiro de 2002. Institui o Código Civil. Diário Oficial [da] República Federativa do Brasil, Brasília, DF, 11 jan. 2002. Disponível em:< http://www.planalto.gov.br/ccivil_03/leis/2002/L10406.htm>. Acesso em: setembro de 2015.

Lei 11.101 de 09 de fevereiro de 2005. Regula a recuperação judicial, a extrajudicial e a falência do empresário e da sociedade empresária. Diário Oficial [da] República Federativa do Brasil, Brasília, DF, 09 fev. 2005. Disponível em:< http://www.planalto.gov.br/ccivil_03/_ato2004-2006/2005/lei/111101.htm>. Acesso em: setembro de 2015.

. Superior Tribunal de Justiça. Recurso Especial no 1.202.077/MS - Mato Grosso do Sul. Relator: Ministro Vasco Della Giustina . Pesquisa de Jurisprudência, Acórdãos, 01 março 2011. Disponível em: < https://ww2.stj.jus.br/processo/pesquisa/>. Acesso em: maio de 2015.

Superior Tribunal de Justiça. Recurso Especial n 680.815 /PR - Paraná. Relator: Ministro Raul Araújo . Pesquisa de Jurisprudência, Acórdãos, 20 março 2014. Disponível em: < https://ww2.stj.jus.br/processo/pesquisa/>. Acesso em: maio de 2015.

BARBOSA, Pedro Henrique Laranjeira. Sucessão Empresarial na Alienação do Estabelecimento Empresarial. 136f. Dissertação (Mestrado em Direito) - Pontifícia Universidade Católica de São Paulo, São Paulo, 2012.

CARVALHOSA, Modesto. Comentários à lei das sociedades anônimas. vol. 4. tomo 1. São Paulo: Saraiva, 1997.

EXAME. Commerce deve manter crescimento forte no Brasil em 2015. Disponível em:< http://exame.abril.com.br/economia/noticias/commerce-deve-manter-crescimento-forte-nobrasil-em-2015>. Acesso em: out. de 2015.

FÉRES, Marcelo Andrade. Estabelecimento Empresarial: Trespasse e Efeitos 
Obrigacionais. São Paulo: Saraiva. 2007.

MACHADO, Alexandre Ricardo; SALEME, Edson Ricardo. Análise da Devida Diligência Empresarial em Direitos Humanos Aplicada na Proteção do Meio Ambiente. In: XXIII CONPEDI, Florianópolis. Anais. Disponível em:<

http://publicadireito.com.br/publicacao/ufsc/livro.php?gt=53>. Acesso em: outubro de 2015.

NEVES, Rúbia Carneiro; GUIMARÃES, Ana Caroline Faria . El Establecimiento virtual y su condición de establecimiento empresarial secundario (filia). In: Panorama of Brazilian Law 2014. v.2, $\mathrm{n}^{\circ}$ 2. Disponível em:<

http://www.panoramaofbrazilianlaw.com/index.php/BrLaw/article/view/30/30>. Acesso em: maio de 2015.

TEPEDINO. Gustavo; et all. Código Civil Interpretado Conforme a Constituição da República. v.III. Rio de Janeiro: Renovar. 2011.

TURCHETTI, Daniela Palhares. Arrendamento do Estabelecimento Empresarial. 2014. 138f. Dissertação (Mestrado em Direito) - Universidade Federal de Minas Gerais, Belo Horizonte. 2014.

WALD, Arnoldo. Do Direito de Empresa. In: TEIXEIRA, Sálvio de Figueiredo (coord.). Comentários ao Novo Código Civil. v. XIV. Rio de Janeiro: Forense. 2005.

ULHOA, Fábio. Curso de Direito Comercial: Direito de Empresa. v.1. São Paulo: Saraiva. 2012 